\title{
The Factors of Professional Training of a Primary School Teacher in the Context of the Second Higher Education
}

\author{
Olena Pavlyk \\ Kryvyi Rih State Pedagogical University \\ Liudmyla Lysohor \\ Kryvyi Rih State Pedagogical University
}

The article highlights the problem of effective education of adults receiving the second higher education. The importance of this problem is related to the specifics of the formation of the contingent of part-time students majoring in 013 Primary education, which is heterogeneous in age, basic education, and professional activity. The data collection methods and methods of quantitative mathematical analysis are used in our pedagogical research. It was found that in the process of professional training of primary school teachers in the second higher education should take into account the following factors: age of students, their needs, social status, the availability of main education, and work due to the specialty. This determines the selection of methods and techniques of teaching, technologies that provide quality practical training, taking into account their professional and life experience, intrinsic motivation and a strong desire for self-realization. The study identified the most effective teaching methods' to be relevant in acquiring the necessary knowledge and skills required for future teachers- the practical, interactive teaching methods, case studies, simulation, problem solving, critical thinking etc.

Keywords: second higher education, adult education, andragogy principles, professional background

\section{INTRODUCTION}

Modernization of the higher education system in Ukraine in modern conditions is caused by the increasing role of the individual who adapts to rapid changes in social and economic life. Over the last decade, the requirements for the professional competence of a graduate of a higher education institution, the degree of his readiness for continuous personal and professional development and self-improvement have significantly increased. To start with, modern social and cultural trends determine the transformation of higher education into a social mechanism of personal development; moreover, these trends focus on training a specialist who can adequately accept the challenges of a society and establish the direction of further activity.

According to observations, the most people choose their profession in a high school, but by no means have all of them then work within their specialty. The final choice of the profession person would like to work and get better in, proceeds commonly in a mature age. In order to acquire a new profession, some specialists get a non-formal education, complete short-term or long-term retraining courses, get certified in retraining programs, engage in self-education or undergo the professional certification. Others enter higher 
education institutions. This is just the one of the reasons that stimulates a person to get a second higher education.

It often happens that the obtained specialty gets actual in a few years due to redistribution processes in the job market, new tendencies in social requests for the certain professions (staff resource redeployment in economics). As a result, there is a reduction in job opportunities and wages. Those who want to be successful and stay in demand, have to change their profession, risk and start all over again. Therefore, today more and more people are mastering new fields of knowledge, getting a second higher education and as a result get new specialty. And this is not only the characteristic property of the Ukrainian labor market, but a global trend generated by the bursting society development in the 21 st century.

Second higher education is an education obtained through the specialized training. Its destination is the improvement of professional skills of a person, expanding and updating his professional knowledge, skills and abilities or obtaining the other specialty on the basis of main education (educational qualification level) and practical experience as a specialist with bachelor's or master's degree. Form of study - full-time or parttime (as the candidate selected).

Thus, demographic leaps, the availability of vacancies, new vacancies lead up to learning throughout the person's life, the intent and necessity to change proficiencies and professions. Based on expert estimates, the number of candidates seeking for a second higher education is growing by $20-30 \%$ annually. This dynamic is unchanged since 2004 to the present. More than $55 \%$ of «adult students» do not improve proficiency, but receive completely different profession. Such trend is nurtured by the presence of the new specialties in the labor market and the current educational trend of «Lifelong Learning» (Varenyk, 2008).

The goals of the article is the identification of factors of effective education of adults receiving the second higher education.

\section{What the Law Says}

The Law of Ukraine «On Higher Education» (as amended on September 25, 2020) states that no one may be restricted in the right to receive the higher education (Section I, Article 4). Citizens of Ukraine have the right to obtain a second higher education free of charge due to the loss of the opportunity to perform official duties according to main education based on the conclusions of the medical and social expert commission (The Law of Ukraine «On Higher Education», 2020). Persons who have obtained the specialist educational and qualification level at the expense of the state budget may obtain a master's degree only at the expense of individuals. The Order of the Ministry of Education and Science of Ukraine "On Approval of the Conditions of Admission to Higher Education Institutions of Ukraine" establishes the rules of admission for persons entering on the basis of a previously obtained main education. There are no age restrictions on obtaining a second higher education in accordance with current legislation. However, some institutions of higher education set a 35-45-year age limit depending on the features of the specialty.

\section{The Reasons to Choose the Second Higher Education}

Today the pedagogical education in the labor market in Ukraine is one of the highly requested among employers. The demand for high-quality educational services is growing every year - modern private educational and development centers are opening. The majority of them provide the development and education of children at preschool and primary education. Graduates who obtain a high-quality second higher education in the specialty 013 Primary education have the ability to work not only as teachers but also as correctional and rehabilitation teachers, methodologists in innovative educational centers, inspectors in children social protection authorities, online academies, etc. The teaching is also providing a career growth - in time it is possible to take the position of deputy headmaster or headmaster, go through the system of teacher training and obtain the pedagogical title of «school counselor». Quite a few masters' graduates, who have successfully mastered the educational program of professional training, are employed abroad and have a significant success. 


\section{Current Practice of Teacher Training in the European Educational System}

In some countries, second higher education is similar to the optional professional course. Due to this condition, anyone can receive a pedagogical education by completing a shortened training program.

Higher pedagogical system in Poland is represented by a number of institutions (universities, higher pedagogical schools and pedagogical academies, as well as academies of physical education), where those who is interested in can obtain a second higher education (specialization) after a two-year retraining program (Poland Teaching Profession, 2021). According to the provisions of the law on education «Karta Nauczyciela», five stages of teacher professional development have been established. At the initial level, it is a «trainee» who teaches in educational institutions for one or two years. After a successful interview with representatives of the educational commission consisting of a mentor, headmaster, head of the pedagogical department of the higher education institution and a trade union representative, the trainee moves to the level of «contract teacher». In this position, the teacher must work at least three years. The next step is to pass a methodical exam, which gives the opportunity to improve the professional qualification to the level of «nominated teacher». In this position, the teacher must work for three years and re-interview with representatives of the educational commission. According to The Polish Education Act now the commission includes: the director of an educational institution or a deputy director, three experts from the Ministry of Education and a trade union representative. The fourth level is a «certified teacher». For the most Polish teachers it is final step in professional development. However, some professionals are trying to reach the fifth level - «professor of education».

In Germany, the procedure for obtaining a second higher education, or Zweitstudium, is no different from the obtaining of the main education. Students study together with those who receive a bachelor's degree for the first time. In such circumstances, the study of professional disciplines takes place at an indepth level, which means full immersion in the specialty: the opportunity to attend a full lecture course, participate in seminars and workshops, as well as practice in educational institutions on a paid basis (The Educational System in the Federal Republic of Germany 2016/2017). Another advantage of the second higher education in Germany is a flexibility of education system, which is implemented in a mixed form. The basic professional training of teachers represents in two stages: a period of practical training at the university and practical training at school. Teacher training programs are provided by the following universities: Technische Hochschulen / Technische Universitäten, Pädagogische Hochschulen (pedagogical colleges). Recently, the percent of active pedagogical school practice related to the courses of higher education has been increasing in the respective training program. In each state teacher training centers are founded that form the chain between higher education institutions and the school in order to ensure the quality of students' pedagogical practice.

The teacher training system in the UK is quite flexible. To become a teacher, you can enroll in courses or a series of courses for students at a university that provides a teacher education. The educational programs of the courses are structured in such a way that allows a student to combine studying and work activities.

To have a right to work in public educational institutions, it is necessary for the job applicant to acquire the level a «qualified teacher status» (QTS). To obtain a QTS, you must have a bachelor's degree or an equivalent qualification. In addition, it is mandatory to pass certification for compliance with the professional standards (Can I get into teaching and education without a degree?).

The UK university teacher-training program includes three components that are close correlated and provide both the basic educational concepts as well as the practical skills needed for successful professional growth. The curriculum addresses all aspects of teacher training, including the development of subject planning skills, teaching, assessment of student achievement, and classroom management. Students under the guidance of university academicians carry out educational and professional research in order to develop and implement modern learning technologies in the educational process. The third component is the pedagogical practice; students go through it in partner schools to train professional competencies (PGCE Education Secondary).

In Finland, there are various teacher-training programs in the higher education system - primary school teachers (grades 1-6) and subject teachers, who provide teaching of different subjects in grades 7-9. For a long time, the primary school teacher is constantly one of the most popular professions. Every year, a large 
number of entrants (up to 7,000 people) who have graduated from high school with honors, seek education in educational programs for primary school teachers (Malinen et al., 2012). In order to become a teacher (both elementary school and subject teacher), you must obtain a master's degree. The duration of relevant university courses is 5 years. Today, the development of the practical skills is the basis of practical training of teachers at the university that helps forward to the extension of professional competencies. Active pedagogical practice starts in the first year of study and provides a combination of theory and practical proficiency. During this period, students observe the activities of teachers and students in the educational process; carry out psychological and pedagogical analysis. During the second and third years of study, students teach all alone, assess trainee achievement and perform the duties of a class teacher. In the fourth year of study, students are participating in meetings of methodological associations of teachers, in the preparation of school activities. While they overcome the difficulties that arise when combining theory with practice, they create their own professional portfolio and fill in reflective learning logs. The portfolio and the reflective study journal are constantly reviewed by the teacher-supervisor of the practice. Then on the basis of it the practical professional activity of students is adjusted. Thus, students are aware of how modern concepts of learning are implemented in the educational process of the school. The management of pedagogical practice is carried out by university academicians and school teachers.

It is worth noting that today in the European educational system, there are similar models of higher pedagogical education, and special attention is focused on practical training.

\section{The Special Aspects of Adult Education}

Today in Ukraine, the strict attention is paid to the development and implementation of an effective policy of adult education and training; such a policy is needed due to the number of reasons. One of the important factors is the Ukraine's entry into the European educational field. This involves the development of all components of the system of Lifelong Learning. Lifelong learning is a tool that ensures the modernization of the economic, social and humanitarian sphere of the country. Adult education provides for the usage of all education forms on all levels, which allow adults who have a main education to acquire new competencies or enhance professional knowledge and skills. According to the definition of the European Association for Adult Education (EAEA), the segment of «adult education and training» in European practice covers formal, non-formal and spontaneous forms of adult education (Kolyshko et al., 2018; Knowles et al., 2005). The second reason is the year-on-year growth of demand for adult education providers. In the field of education for adults, Ukraine is endowed with a number of international instruments, unilateral and bilateral agreements, which outline certain issues of adult education, especially, such international instruments as the Incheon Declaration and Framework for Action (Education 2030: Incheon Declaration and Framework for Action, Paris, UNESCO, 2015); Sustainable Development Goals to 2030, (CSD) №4 in the Final Document of the UN Summit «Transforming our world: an agenda for sustainable development until 2030» (adopted in 2015 and ratified by Ukraine in 2016) (Sustainable Development Goals to 2030, 2020); Priorities of the Eastern Partnership until 2020 (Priorities of the Eastern Partnership until, 2020); Hamburg Declaration of UNESCO, 1997 (Hamburg Declaration of UNESCO, 1997); Association Agreement between Ukraine and the EU (Association Agreement between Ukraine and the EU, 2017).

The Law of Ukraine «On Education» of 05.09.2017 № 2145-VIII (as amended on 16.11.2020) in Article 18 states that adult education is a component of lifelong learning which aimed to the enforcement of the of every adult to lifelong learning, with respect to his/her personal needs, priorities of social development and the needs of the economy. The components of adult education are postgraduate education; professional training of employees; retraining or advanced training courses; continuous professional development; any other components provided by the legislation, offered by the subject of educational activity or defined by the person (The Law of Ukraine «On Higher Education», 2020).

In order to determine the specific aspects of professional training of primary school teachers who receive a second higher education, we conducted a study of a student quota who have chosen the specialty 013 Primary Education of Kryvyi Rih State Pedagogical University (external study mode) and graduated the university with bachelor and master degree over the last two years. To collect experimental data, a 
Google form of a questionnaire was developed, which provides clarification of issues related to rethinking approaches to training. 77 respondents took part in the research. The following parameters were analyzed: age, basic education, level of education, availability of practical experience in the second specialty in general secondary education institutions, advantages and difficulties that appeared in the process of obtaining a second higher education.

Analyzing the age characteristics of the respondents, we found that 12 students are aged 24-30 years, which is $15.6 \%, 18$ students aged $31-35$ years $(23.4 \%), 29$ students aged $36-40$ years $(37.6 \%)$, and only 6 students aged 41-45 years (7.8\%), and 12 students aged 46-52 years (15.6\%). Thus, most of them (37.6\%) are aged 36-40 years (Figure 1). At this age is the time for midlife crisis, critical assessment and reinterpretation of life positions, there is common dissatisfaction in the professional and family life, the maturity comes that forces to changes, to acquire another education, profession (Pohribnyak, 2013; Baranovska et al., 2014; Dzyuba et al., 2013; Lukyanova, 2015; Panchenko, 2013). This encourages a person to finally realize a child's dream, to get rid of the state of unrealization. This thesis is confirmed by the results of interviews with respondents, among whom $46(59.7 \%)$ indicated that they came to get a second higher education because of the aspiration, which is the strongest motivating factor in learning.

Most studies show that adults obtain a second higher education mainly due to the redistribution of the labor market, job loss. According to our data, this percentage is only $10(7.7 \%)$. However, our study found another trend that few people talk about. In addition, it is mainly related to the personal needs of higher education students, their mental state.

Basically, according to the analysis of the age-related characteristics of the respondents, it is clear that the maximum age of the students is 52 years. The average age of those who obtain a second higher education is 35.2 years. Adult students are anxious about decrease in memory and mental activity. According to the respondents, it is difficult for them to assimilate and memorize a large amount of new material, professional terminology, which has a negative impact on educational and professional activities. This should be taken into account when appropriate teaching methods and technologies are selected. It is also important to keep in mind the fact that adult students obviously have children, feel responsibility for their own lives and the environment. Considering the age characteristics of the student contingent, we think, it would make sense to offer them a flexible system of education, the ways to organize self-education and mutual education.

\section{FIGURE 1 AGE CHARACTERISTICS OF RESPONDENTS}

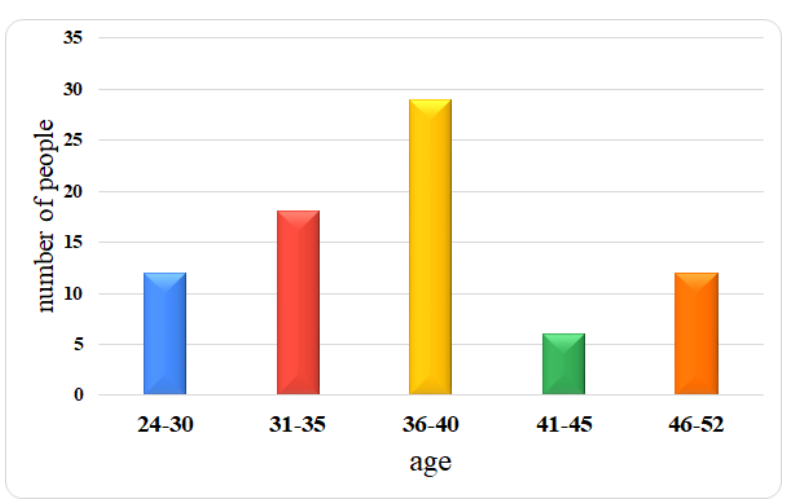

To find out how the contingent of students who obtain the second higher education is formed, we analyzed the main education obtained by them in the fields of knowledge (Figure 2). The analysis of the student's answers testifies that students seeking for the second higher education in the specialty 013 Primary education, previously had such professions as: 1 law (1.3\%), 19 engineers $(24.9 \%), 29$ were specialists in management and administration (34.7\%), 25 students had basic pedagogical education (32.9\%), 2 students $(2.6 \%)$ had a degree in culture and art, 1 respondent $(1.3 \%)$ represented such area of knowledge as social and behavioral sciences and professional. So, most of them have basic economic, pedagogical and technical 
education. A specific of the specialty 013 Primary education allows you to successfully use the knowledge of the previous profession and implement those skills in the second specialty. For example, one respondent claims, «after my main education, I am a marketing expert, which allows me to offer students a variety of creative ways to present educational material. The main task of the teacher is to interest the children, motivate them to learn, to reveal the relevance and importance of information, to make the learning process accessible».

\section{FIGURE 2 \\ THE FIRST EDUCATION OF RESPONDENTS BY THE FIELD OF KNOWLEDGE}

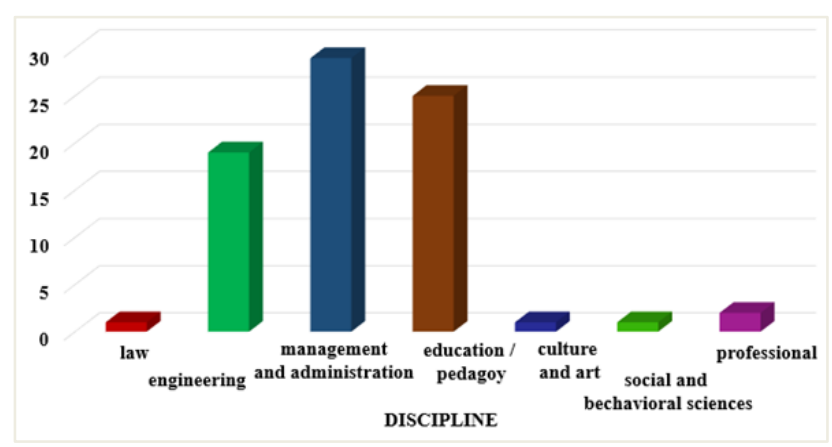

The next criterion for the analysis was the level of the main education (Figure 3). The analysis of the personal data shows that 47 of respondents have master's degree, which is $61.2 \%$. Respectively, 11 (14.2\%) students have a bachelor's degree and $19(24.6 \%)$ have junior specialist degree.

FIGURE 3

FIRST HIGHER EDUCATION

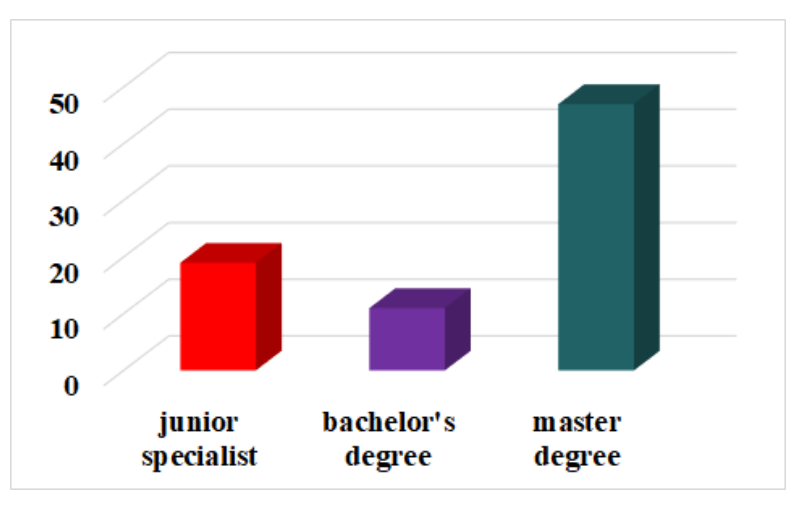

According to observations of the educational process and interviews with applicants for second higher education, the most successful students are those with a basic higher education and a master's degree. They usually able to rank data quickly know well how to work with literature, interpret it, draw conclusions, have strong skills of critical thinking and communication, self-education and self-organization. Students with a basic degree of junior specialist are less successful in their studies, because they do not always own the techniques of effective information processing, skills in working with literature. This criterion, in our opinion, should be taken into account when the educational process is organized.

An important factor is the availability of practical experience in the second specialty (Figure 4). According to our surveys, 54 students (70.1\%) work according to their specialty. They thirst for knowledge, study with interest, show activity, rethink their own pedagogical experience, share their failures and achievements, give useful practical advice to classmates. 


\section{FIGURE 4 \\ EMPLOYMENT ACCORDING TO THE SECOND EDUCATION}

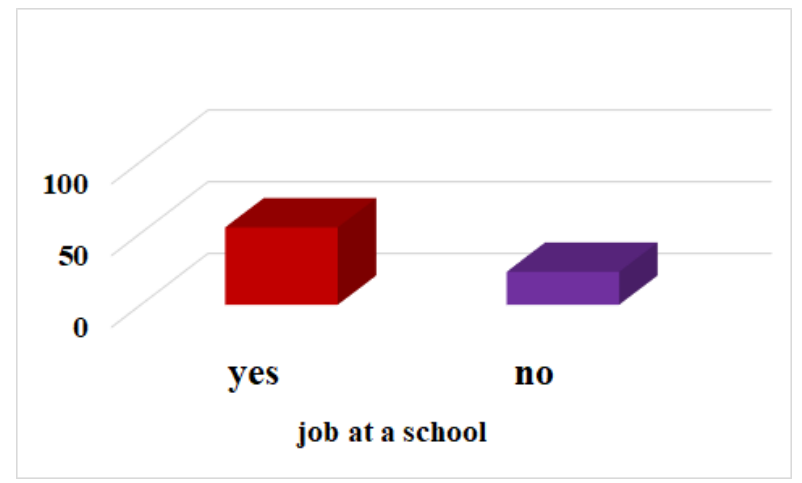

Thus, age, practical experience, higher education or even several educations, including pedagogical, require fundamentally new approaches to learn, because adults learn differently when motivated by professional needs in the acquisition of subject and methodological competencies. At the same time, we have to overcome a number of difficulties related to stereotypes about forms, educational environment, activities, assessment and self-assessment, etc.

The development and implementation of adult education policies is a challenge of the present time, which is becoming increasingly important in an era of rapid digitalization and a dynamic change on labor market. Adults (those who have practical experience, hold certain positions) need to update constantly their knowledge in order to meet the demands of employers. Accordingly, a new direction is founded in pedagogical science, which reveals the problems, prospects, features of adult education throughout life andragogy.

Modern andragogy distinguishes 11 defining principles (provisions) that must be considered during the planning and conducting of training sessions (Merriam et al., 2013; Rogers, 2011). We think that it is important to consider the five most important of them in the process of training students who receive a second higher education in the specialty 013 Primary Education.

The first principle is the priority of self-study. This means that in order to develop the theoretical part of the discipline, it is necessary to develop a research framework (guide) for students with appropriate practical tools for its processing.

The second principle is the organization of a group work. As practice shows, cases for practical work should be offered to students to perform in groups. This in turn leads to increased levels in communication, provides the exchange of professional experience and significantly improves the quality of their performance, as well as the preparation for exams.

The use of professional experience as a source of new knowledge is the third important principle that ensures the exchange of experience, the transfer of information to each other and the production of new ideas in the discussion. Therefore, during the lectures and practical classes it is important to use discussions with problematic topics that actuate a critical rethinking of the implementation of modern pedagogical concepts, technologies and techniques. In addition, it is advisable to introduce intersessional consultations in order to implement independent project tasks more effectively.

Andragogs also highlight the principle of relevance of knowledge and experience. Therefore, in the classes it is advisable to consider the cases of students, with which you can explain the mistakes and suggest effective ways to solve them.

An important principle of adult education is self-motivation. This principle allows students to choose the topic on which they develop their own projects for independent work, work on course, bachelor's and master's studies. 


\section{CONCLUSIONS}

To conclude, we emphasized that's learning of adult students should take place through the understanding of their own professional and life experience, taking into account their age, main education, personal needs.

1. It was determined the key factors of professional training of a primary school teacher: age of students, their needs, social status, the availability of main education, and work due to the specialty. This determines the selection of effective practical methods and techniques of teaching, technologies that provide quality training for forming them professional skills and competences.

2. Acquisition of the second higher education should be based on the principles of andragogy, such as the transformation of experience, its rethinking, with the attention to the analysis of practice-oriented cases, pedagogical situations, collaboration, integration of knowledge from the main and the second higher education, experience. The organization of such training should be flexible, to use distance and mixed form of learning. An important aspect is the assimilation of specific terminology, improving the culture of professional speech.

3. The process of professional training of primary school teachers in the context of the second higher education, it is important to ensure a practice-oriented approach, flexible learning, involvement of professional communities of responsible teaching, non-formal and informal education. In addition, professional training should include the formation of skills to choose quality educational content, develop educational programs, plan the educational process, and ensure the system and manufacturability of education.

\section{REFERENCES}

Association Agreement between Ukraine and the EU. (2017). Retrieved from https://www.kmu.gov.ua/en/yevropejska-integraciya/ugoda-pro-asociacyu

Baranovska, LV., \& Baranovskyi, M.M. (2014). Conseptual aspect of the adult education in Ukrainian system of higher education. Bul. Nat. Aviat. Univ. Pedagogy. Psychology, 5(1), 14-19. Retrieved from http://er.nau.edu.ua/handle/NAU/28541

Dzyuba, T.M., \& Kovalenko O.H. (Ed.). (2013). Psykholohiya doroslosti z osnovamy herontopsykholohii. PNPU by V.H. Korolenko. Retrieved from http://dspace.pnpu.edu.ua/bitstream/123456789/5250/1.pdf

Eastern Partnership. (2020). European Neighbourhood Policy and Enlargement Negotiations. Retrieved from https://ec.europa.eu/neighbourhood-enlargement/neighbourhood/eastern-partnership_en

Knowles, M.S., Holton, E.E., \& Swanson, R.A. (2005). The Adult Learner: The Definitive Classic in Adult Education and Human Resource Development (6th ed., p.378). ELSEVIER Butterworth Heinemann, London, New York.

Kolyshko, R., \& Lazorenko, O. (2018). What should be the policy of adult education in Ukraine? Analytical report. IOP Publishing Project "Hromadska synerhiya". Retrieved from https://www.civic-synergy.org.ua/analytics/yakoyu-maye-buty-polityka-navchannya-doroslyh-vukrayini/

Lukyanova, L.B. (2015). Acmeological resource of andragogical learning model. Problems of Education, 84, 31-36. Retrieved from https://core.ac.uk/download/pdf/42974921.pdf

Malinen, O-P., Väisänen, P., \& Savolainen, H. (2012). Teacher education in Finland: A review of a national effort for preparing teachers for the future. Cur. J., 23(4), 567-584. doi.org/10.1080/09585176.2012.731011

Merriam, Sh., \& Bierema, L. (2013). Adult Learning: Linking Theory and Practice (p.320). Jossey-Bass. Retrieved from https://www.wiley.com/enus/Adult+Learning\%3A+Linking+Theory+and+Practice-p-9781118130575 
Panchenko, S.M. (2013). Psychological features of an adult as a subject of learning. Bul. Nat. Acad. St. Border Guard Serv. Uk., 3. Retrieved from http://nbuv.gov.ua/UJRN/Vnadps_2013_3_35

Pohribnyak, H. (2013). Certain aspects of the middle age crisis. IOP Publishing Scientist Conferences. Retrieved from http://oldconf.neasmo.org.ua/node/1817

Poland Teaching Profession. (2021). Retrieved from https://education.stateuniversity.com/pages/1217/Poland-TEACHING-PROFESSION.html

Rogers, A. (2011). Teaching Adults ( ${ }^{\text {th }}$ edn.). Open University Press, Milton Keynes, United Kingdom, 360.

TARGETcareers. (n.d.). Can I get into teaching and education without a degree? Retrieved from https://targetcareers.co.uk/career-sectors/teaching-and-education/170-can-i-get-into-teaching-andeducation-without-a-degree

The Educational System in the Federal Republic of Germany 2016/2017. A description of the responsibilities, structures and developments in educational policy for the exchange of information in Europe. (n.d.). Retrieved from

https://www.kmk.org/fileadmin/Dateien/pdf/Eurydice/Bildungswesen-engl-pdfs/teachers.pdf

The Law of Ukraine «On Higher Education». (as amended on September 2020). Retrieved from https://zakon.rada.gov.ua/laws/show/2145-19?lang=en\#Text

UNDP. (2020). Sustainable Development Goals. Retrieved from https://www.ua.undp.org/content/ukraine/en/home/sustainable-development-goals.html

UNESCO Digital Library. (1997). Adult education: The Hamburg Declaration; the Agenda for the Future. Retrieved from https://unesdoc.unesco.org/ark:/48223/pf0000116114

UNESCO Institute. (2015). Education 2030: Incheon Declaration and Framework for Action Towards inclusive and equitable quality education and lifelong learning for all. UNESCO IITE. Retrieved from https://iite.unesco.org/publications/education-2030-incheon-declaration-framework-actiontowards-inclusive-equitable-quality-education-lifelong-learning/

University of Bristol. (n.d.). Education (Secondary) (PGCE). Retrieved from http://www.bristol.ac.uk/study/postgraduate/2021/ssl/pgce-education/

Varenyk, N. (2008). Adult students: Luxury or urgent need? Zerkalo Nedely. Ukrayna, 41. Retrieved from https://zn.ua/ukr/SOCIUM/dorosli_studenti_rozkish_chi_nagalna_potreba 